\title{
Teaching NeuroImages: A rare case of Jacobsen syndrome with global diffuse hypomyelination of brain
}

Himadri Patel, Ashutosh Kumar, MD, Gerald Raymond, MD, and Gayatra Mainali, MD

Neurology ${ }^{\circledR}$ 2019;92:e1665-e1666. doi:10.1212/WNL.0000000000007234

\author{
Correspondence \\ H. Patel \\ Hpatel12@ \\ pennstatehealth.psu.edu
}

Figure $1 \mathrm{MRI}$ brain at 18 months of age

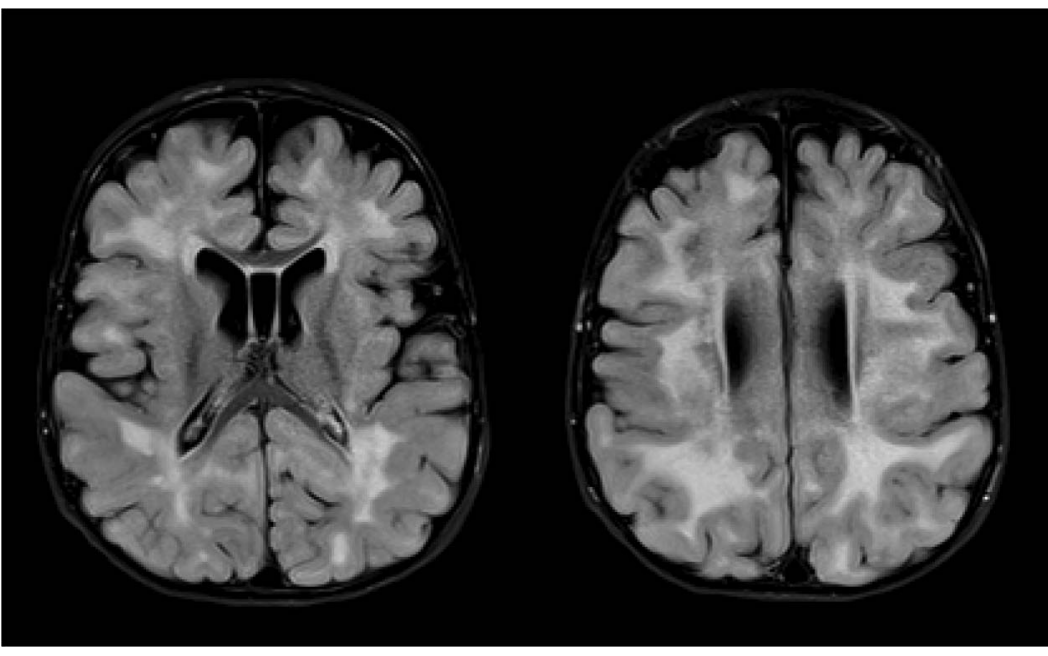

Axial fluid-attenuated inversion recovery MRI shows white matter hypomyelination of cerebral as well as deep white matter consistent with leukodystrophy.
An 8-month-old boy presented with developmental delay, diffuse hypotonia, hypoplastic left heart syndrome, undescended testes, neonatal thrombocytopenia, and unusual facies. Chromosome microarray showed an 11q23-11q24 deletion, consistent with Jacobsen syndrome (JS).

Initial head MRI at 18 months showed severe diffuse hypomyelination of cerebral white matter believed to be consistent with leukodystrophy (figure 1). Repeat MRI at 3 years of age showed less extensive hypomyelination (figure 2). The child, while still delayed, had made some developmental progression.

While delayed myelination has been reported, there are few reports of neuroimages. Awareness of the MRI presentation of JS is crucial to prevent unnecessary evaluation in this condition. ${ }^{1,2}$

\section{Study funding}

No targeted funding reported.

\section{Disclosure}

H. Patel and A. Kumar report no disclosures relevant to the manuscript. G. Raymond is a consultant for the Department of Health and Human Services, Minoryx (Barcelona), Bluebird

\section{MORE ONLINE}

$\rightarrow$ Teaching slides

links.lww.com/WNL/ A848

From Penn State College of Medicine (H.P.); and Department of Pediatric Neurology (A.K., G.R., G.M.), Penn State Hershey Medical Center, Hershey, PA.

Go to Neurology.org/N for full disclosures. Funding information and disclosures deemed relevant by the authors, if any, are provided at the end of the article. 
Figure 2 MRI brain at 3 years of age

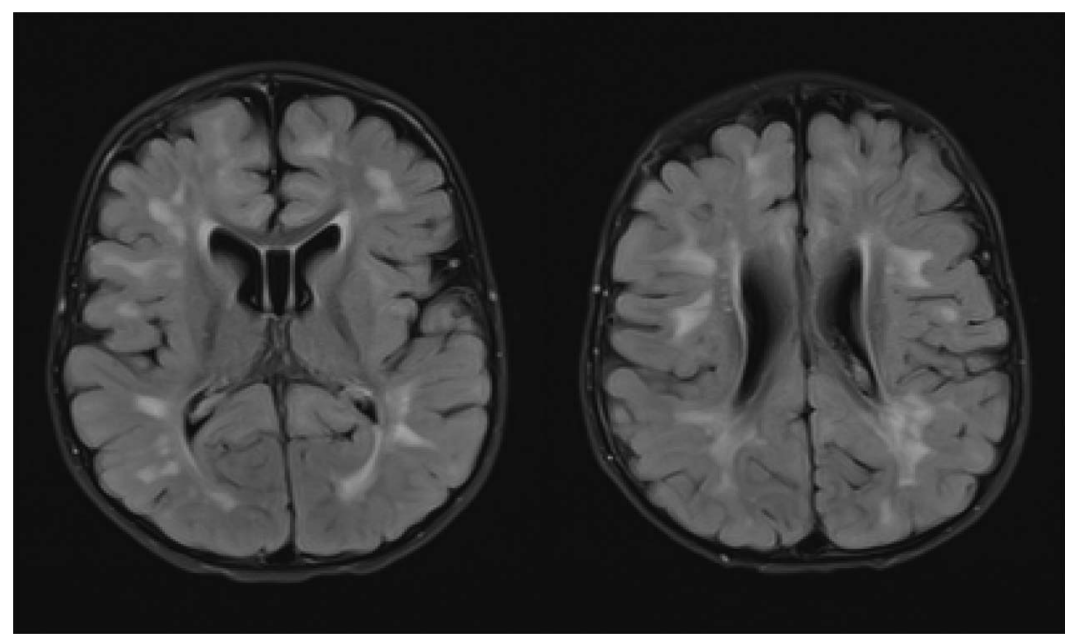

Axial fluid-attenuated inversion recovery MRI shows improved degree of white matter myelination.

bio (Cambridge, MA), and Viking Therapeutics (San Diego, $\mathrm{CA}$ ), and previously served as a consultant for Shire and Vertex (Boston, MA). G. Mainali reports no disclosures relevant to the manuscript. Go to Neurology.org/ $\mathrm{N}$ for full disclosures.

\section{References}

1. Favier R, Akshoomoff N, Mattson S, Grossfeld P. Jacobsen syndrome: advances in our knowledge of phenotype and genotype. Am J Med Genet C Semin Med Genet 2015; 169:239-250.

2. Yu F, Carter JE, Bazan C III. A case of Jacobsen syndrome with multifocal white matter lesions. Clin Imaging 2016;40:705-706.

\section{Appendix Authors}

\begin{tabular}{llll}
\hline Name & Location & Role & Contribution \\
\hline $\begin{array}{l}\text { Himadri } \\
\text { Patel }\end{array}$ & $\begin{array}{l}\text { Penn State } \\
\text { College of } \\
\text { Medicine }\end{array}$ & Author & $\begin{array}{l}\text { Conceptualized the case } \\
\text { report; drafted and revised the } \\
\text { manuscript for intellectual } \\
\text { content }\end{array}$ \\
\hline $\begin{array}{l}\text { Ashutosh } \\
\text { Kumar }\end{array}$ & $\begin{array}{l}\text { Penn State } \\
\text { Hershey } \\
\text { Medical Center }\end{array}$ & Author & $\begin{array}{l}\text { Conceptualized the case } \\
\text { report; drafted and revised the } \\
\text { manuscript for intellectual } \\
\text { content }\end{array}$ \\
\hline $\begin{array}{l}\text { Gerald V. } \\
\text { Raymond }\end{array}$ & $\begin{array}{l}\text { Penn State } \\
\text { Hershey } \\
\text { Medical Center }\end{array}$ & Author & $\begin{array}{l}\text { Conceptualized the case } \\
\text { report; revised the manuscript } \\
\text { for intellectual content }\end{array}$ \\
\hline $\begin{array}{l}\text { Gayatra } \\
\text { Mainali }\end{array}$ & $\begin{array}{l}\text { Penn State } \\
\text { Hershey } \\
\text { Medical Center }\end{array}$ & Author & $\begin{array}{l}\text { Conceptualized the case } \\
\text { report; revised the manuscript } \\
\text { for intellectual content }\end{array}$ \\
\hline & &
\end{tabular}




\section{Neurology}

\section{Teaching NeuroImages: A rare case of Jacobsen syndrome with global diffuse hypomyelination of brain}

Himadri Patel, Ashutosh Kumar, Gerald Raymond, et al.

Neurology 2019;92;e1665-e1666

DOI 10.1212/WNL.0000000000007234

This information is current as of April 1, 2019

\section{Updated Information \& Services}

References

Citations

Subspecialty Collections

Permissions \& Licensing

Reprints including high resolution figures, can be found at: http://n.neurology.org/content/92/14/e1665.full

This article cites 2 articles, 0 of which you can access for free at: http://n.neurology.org/content/92/14/e1665.full\#ref-list-1

This article has been cited by 2 HighWire-hosted articles: http://n.neurology.org/content/92/14/e1665.full\#\#otherarticles

This article, along with others on similar topics, appears in the following collection(s):

All Genetics

http://n.neurology.org/cgi/collection/all_genetics

All Pediatric

http://n.neurology.org/cgi/collection/all_pediatric

Developmental disorders

http://n.neurology.org/cgi/collection/developmental_disorders Leukodystrophies

http://n.neurology.org/cgi/collection/leukodystrophies

MRI

http://n.neurology.org/cgi/collection/mri

Information about reproducing this article in parts (figures,tables) or in its entirety can be found online at:

http://www.neurology.org/about/about_the_journal\#permissions

Information about ordering reprints can be found online:

http://n.neurology.org/subscribers/advertise

Neurology ${ }^{\circledR}$ is the official journal of the American Academy of Neurology. Published continuously since 1951, it is now a weekly with 48 issues per year. Copyright @ 2019 American Academy of Neurology. All rights reserved. Print ISSN: 0028-3878. Online ISSN: 1526-632X.

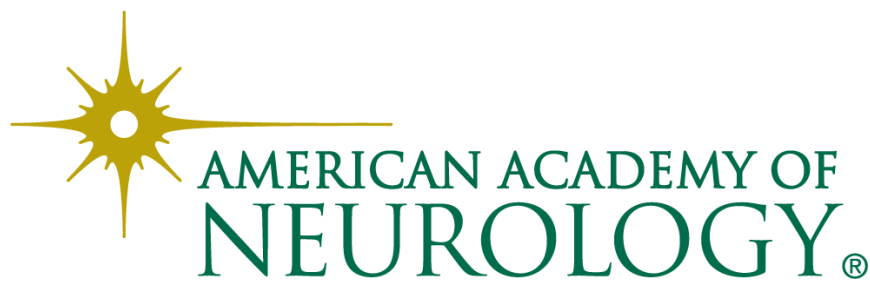

